
3 Research Square
Preprints are preliminary reports that have not undergone peer review.
They should not be considered conclusive, used to inform clinical practice,
or referenced by the media as validated information.

\title{
The Efficacy of Olanzapine-Contained Antiemetic Therapy for Breast Cancer Patients: A Systematic Review and Pooled Analysis
}

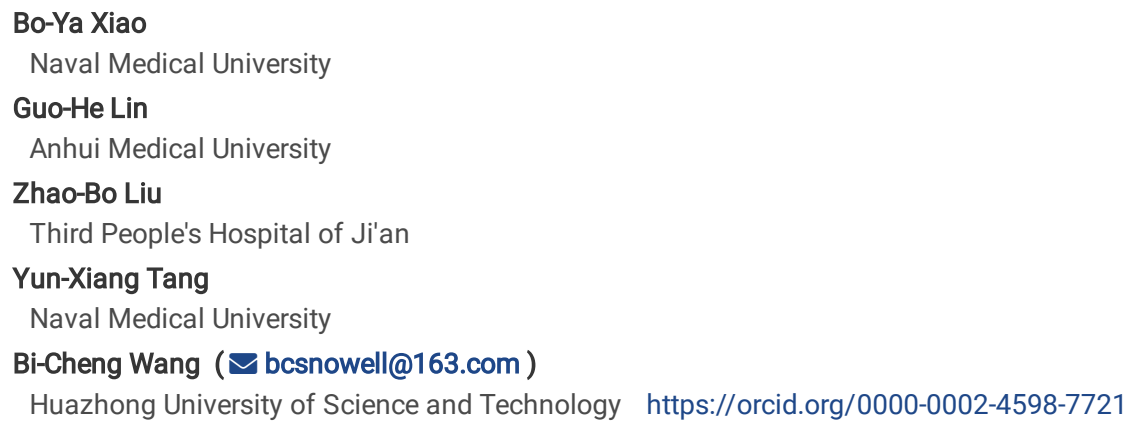

Keywords: olanzapine, breast cancer, antiemetic therapy, meta-analysis

Posted Date: August 13th, 2021

DOI: https://doi.org/10.21203/rs.3.rs-702221/v1

License: (c) (i) This work is licensed under a Creative Commons Attribution 4.0 International License. Read Full License 


\section{Abstract}

Purpose: As an antipsychotic agent that targets multiple neurotransmitter receptors, olanzapine has been added to antiemetic therapies. However, olanzapine is rarely used in the real-world antiemetic strategies for breast cancer patients who suffered chemotherapy-induced nausea and vomiting. Therefore, in this study, we comprehensively reviewed the antiemetic researches related to olanzapine and pooled analyzed the results from clinical studies to confirm the efficacy of olanzapine in preventing nausea and vomiting in breast cancer.

Methods: PubMed, Web of Science, EMBASE, and Cochrane Central databases were searched from inception through April 19, 2021. Both prospective and retrospective studies were eligible. The primary outcomes were complete response (defined as no vomiting and no use of rescue medications) and no nausea rate.

Results: Five studies were identified in the systematic review, four of which with 466 breast cancer patients were included in the pooled analysis. In the acute period (0-24 hours), the olanzapine group had significantly higher rates of complete response ( $71.3 \%$ vs $48.1 \%$, odds ratio [OR]: $2.66,95 \%$ confidence interval [Cl] 1.39-5.11, $\mathrm{p}=0.003)$ and no nausea $(70.0 \%$ vs $43.0 \%, \mathrm{OR}: 3.55,95 \% \mathrm{Cl} 1.76-7.18, \mathrm{p}=0.04)$ than the placebo group. While in the delayed period, the olanzapine group was also superior to the placebo group in terms of the complete response ( $82.5 \% \mathrm{vs} 63.3 \%, 0 \mathrm{R}: 3.81,95 \% \mathrm{Cl} 1.58-9.15, \mathrm{p}=0.003)$ and no nausea (66.3\% vs $51.9 \%$, OR: $2.08,95 \% \mathrm{Cl} 1.03-4.21, \mathrm{p}=0.04)$ rates. During the overall period in prospective studies, the proportions of complete response $(50.0 \%$ vs $34.2 \%$, OR: $1.93, p=0.04)$ and no nausea $(51.3 \%$ vs $25.3 \%$, OR: $3.40, p=0.0006)$ in the olanzapine group were higher than those in the placebo group.

Conclusion: Highly emetogenic chemotherapy breast patients could benefit from olanzapine-contained antiemetic therapy. Furthermore, since the cost is low, olanzapine is worth further clinical application and promotion.

\section{Introduction}

Breast cancer is the most common malignant disease in women worldwide. In neoadjuvant, adjuvant, or palliative treatments of breast cancer, anthracycline combined with cyclophosphamide (AC) is generally used. However, with great tumor responses, AC brings over $90 \%$ frequency of emesis.

Because AC is defined as a highly emetogenic regimen, a triple-drug antiemetic regimen (comprising neurokinin-1[NK1] receptor antagonist[RA], 5hydroxytryptamine[5-HT] RA, and dexamethasone) is preferred for all breast cancer patients receiving AC. But there were still over half of breast cancer patients suffering chemotherapy-induced nausea or vomiting (CINV) [1-3].

Olanzapine, an antipsychotic agent, targets multiple neurotransmitter receptors, including dopaminergic, serotonergic, adrenergic, histaminergic, and muscarinic receptors. The mechanism of olanzapine in the improvement of CINV might be the direct blocking of the 5-HTRA. In the National Comprehensive Cancer Network guideline of antiemesis, low dose olanzapine 5/10 mg (days 1-4), combined with standard triple antiemetic therapy, has been recommended to prevent CINV in patients receiving highly emetogenic chemotherapy.

Although previous analyses found that combining olanzapine with standard antiemetic regimens significantly decreased CINV occurrence, and 5 mg olanzapine might be more appropriate for cancer patients $[4,5]$. However, the analysis of olanzapine in treating breast cancer-related CINV was absent.

In the real world of antiemetic therapy for patients with breast cancer, the clinical application of olanzapine is sporadic. Therefore, we conducted this study to review and pooled analyze the results of olanzapine in prospective and retrospective studies for better preventing CINV in breast cancer.

\section{Methods}

The Preferred Reporting Items for Systematic Reviews and Meta-analyses (PRISMA) reporting guideline was used in this study [6].

\section{Search strategy and study selection}

A systematic search was conducted in PubMed, Web of Science, EMBASE, and Cochrane Database on April 19, 2021. As a result, additional studies in review articles were identified. The search strategy applied was "olanzapine or Zyprexa", "breast cancer", "nausea or vomiting", "trial or study", which were used by two of us (BY X and BC W).

\section{Selection criteria}

Inclusion criteria included: (1) Patients: patients were diagnosed with breast cancer; (2) Interventions and Comparisons: patients were treated triple or double antiemetic therapy with or without olanzapine; (3) Outcomes: data of complete response, no nausea, and/or no vomiting rates were available; (4) studies were prospective or retrospective studies. Exclusion criteria: (1) single-arm trials; (2) studies not published in English. Any disagreements in the selection process were resolved by discussion.

\section{Data extraction and quality assessment}

The complete response and no nausea data were extracted by BY X and BC W independently and discussed with another of us (T S). Since the complete response was defined as no vomiting and rescue drug use and no vomiting were not adequate, the no vomiting rates were not analyzed. Other details regarding the name of the first author, year of publication, study design, region, number of patients, age, treatment characteristics were recorded as reported in Table 1. JADAD scoring scale was used to assess the quality of the prospective studies. The Newcastle-Ottawa Scale (NOS) was used to evaluate the trial 
quality by assessing selection, comparability, and outcome for case-control studies. The selection and outcome or exposure domain that meets the criteria are given a star, while the comparability domain has a maximum of 2 stars. The maximum of stars is 9 points. 7-9 points meant high quality, and 0-7 meant low quality.

\section{Statistical analysis}

The main outcomes for our analysis were the total number of complete response and no nausea following standard antiemetic therapy with or without olanzapine. Heterogeneity of the data was evaluated by forest plots, chi-squared tests and quantified by $\mathrm{I}^{2}$ statistic percentages. When $\mathrm{I}^{2}>50 \%$ (defined as high heterogeneity), a random-effects model was applied. While $R^{2} 50 \%$ (defined as low heterogeneity), a fixed-effects model should be adopted. The odds ratios (ORs) and $95 \%$ confidence interval $(\mathrm{Cl})$ of complete response and no nausea were done using RevMan 5.3 software. $p<0.05$ was considered statistically significant.

\section{Results}

\section{Search results}

A total of 150 study records were identified. After title and abstract screening, 36 studies remained. 31 studies were furtherly excluded since they were review/comments/letters, meeting abstracts, protocols, and single-arm studies. Finally, five studies with 684 breast cancer patients met the inclusion and exclusion criteria (Figure 1). However, owing to the raw data in Clemons's study were reported in the form of each cycle of chemotherapy, only results in the other two prospective trials with 159 patients and two retrospective studies with 307 patients were collected for further pooled analysis [1, 3, 7, 8].

The eligible studies published between 2018 and 2020 were showed in Table 1. Patients from Thailand, Canada, China, and Japan were enrolled. Median or mean age ranged from 47.37-55.5. The dose of olanzapine included $10 \mathrm{mg}$ (days 1-4/5) and $5 \mathrm{mg}$ (days 1-4). Standard triple

(aprepitant+ondansetron+dexamethasone) and double (ondansetron+dexamethasone \pm metoclopramide) antiemetic strategies had been combined with or without olanzapine. Doxorubicin or epirubicin plus cyclophosphamide chemotherapy were administrated in all the studies.

\section{Complete response rate}

During the acute, delayed, and overall period published by prospective studies, forest plots showed that adding olanzapine to standard antiemetic therapy significantly increased the complete response rates (acute: $71.3 \%$ vs $48.1, \mathrm{OR} 2.66,95 \% \mathrm{Cl} 1.39-5.11, \mathrm{p}=0.003$; delayed: $82.5 \%$ vs $63.3 \%$, OR 3.81 , $95 \% \mathrm{Cl} 1.58$ 9.15, $\mathrm{p}=0.003$; overall: $50.0 \%$ vs $34.2 \%$, OR 1.93, 95\% Cl 1.02-3.66, $\mathrm{p}=0.04$ ) (Table 2 and Figure 2). However, there was no significant difference between the two groups in terms of complete response in retrospective studies $(47.4 \%$ vs 43.5, OR $1.39,95 \% \mathrm{Cl} 0.38-5.13, \mathrm{p}=0.62)($ Table 2$)$.

\section{No nausea rate}

Pooled results showed that, in terms of no nausea rates, the olanzapine group was superior to the placebo group in the acute (70.0\% vs $43.0 \%$, OR $3.55,95 \% \mathrm{Cl}$ $1.76-7.18, \mathrm{p}=0.0004)$, delayed ( $66.3 \%$ vs $61.9 \%$, OR $2.08,95 \% \mathrm{Cl} 1.03-4.21, \mathrm{p}=0.04)$, and overall $(51.3 \%$ vs $25.3 \%, \mathrm{OR} 3.4,95 \% \mathrm{Cl} 1.68-6.86, \mathrm{p}=0.0006) \mathrm{period}$ (Table 2 and Figure 3).

\section{Bias assessment}

Two studies published by Tienchaiananda and Clemons were randomized, double-blind, placebo-controlled trials, while the other study conducted by Yeo was a randomized, open-label trial. Additionally, two enrolled retrospective studies scored 6 with low qualities. Based on the JADAD and NOS scores, the risk of bias of this meta-analysis was low to moderate in the section of prospective trials but high in the section of retrospective studies.

\section{Discussion}

This study synthesized four eligible clinical study data and pooled analyzed the effects of adding olanzapine to standard double or triple antiemetic therapies in breast cancer patients. Our analysis suggests that breast cancer received highly emetogenic regimens could benefit from olanzapine-contained antiemetic therapy. Even Clemons's prospective study was not included in the analysis, data in the trial provided us insights into the olanzapine-contained antiemetic therapy. During the overall period, the complete cycle response was $41.8 \%$ in the olanzapine group versus $32.4 \%$ in the control group following each cycle of chemotherapy. In addition, in terms of overall nausea control, olanzapine significantly decreased the rate from $41.3-27.7 \%$ [9].

Complete response rates were contradictory among the eligible retrospective studies. Kawazoe's study showed that olanzapine increased the rate of complete response by 2.86-fold [3]. But Suehiro failed to find any significant differences [1]. In retrospective studies, it should be hard for researchers to collect accurate data. Additionally, the absence of controls based on the analyses in these two studies showed that the quality of these two studies was low. Therefore, we still considered that breast cancer patients could benefit from the administration of olanzapine.

However, olanzapine provides meaningful improvements in controlling CINV. Why do oncologists seldom use this drug? First, oncologists do not know much about psychological drugs, like olanzapine. As a traditional psychological drug, high-dose olanzapine (15-20 mg) has been used to treat psychological disorders, including depression [10]. Since the blocking of 5-HT3 receptor by olanzapine, low dose olanzapine 5 mg were administrated to treat CINV. We have noticed that the standard antiemetic regimens usually comprised aprepitant. However, in many developing countries with limited resources, cancer patients do not have access to NK-1 RA. While olanzapine is not expensive and easily available, thus aprepitant could be replaced by olanzapine for patients who suffered CINV [8]. 
Second, even CIVN in cancer patients is tolerated, the necessity of adding olanzapine to standard antiemetic therapy is still in doubt. In Navari's study, patients with breast cancer, lung cancer, or other cancers were treated with olanzapine-contained antiemetic therapy. Results found that the complete response rates were significantly increased with olanzapine during the acute ( $86 \%$ versus $65 \%, p<0.001)$, delayed ( $67 \%$ versus $52 \%, p=0.007$ ), and overall periods ( $64 \%$ versus $41 \%, p<0.001$ ) compared with placebo [4]. In another large-scale phase 3 randomized study, Hashimoto showed that olanzapine 5 mg plus aprepitant, palonosetron, and dexamethasone achieved a $79 \%$ complete response rate versus $66 \%$ in the placebo group, and suggested this four-drug antiemetic strategy to be a new standard antiemetic therapy for cancer patients undergoing highly emetogenic chemotherapy [11].

Additionally, the administration of olanzapine had been demonstrated to improve depression [12]. Depression is the most common psychological symptom among patients with breast cancer [13]. According to the study reported by Ju, over $50 \%$ of breast cancer patients had at least mild depression [14]. The prevalence of depression in developing countries was twice as high as in developed countries [15]. Although evidence of low-dose olanzapine both in treating CINV and breast cancer-related depression has not been certificated, psychological intervention is critically essential for breast cancer patients.

Third, increased olanzapine-related adverse events might be an obstacle. Weight gain, increased blood sugar, somnolence, fatigue, and anorexia are common olanzapine-related adverse events. However, low dose olanzapine was well tolerated and did not markedly increase the incidences of body weight, fatigue, somnolence, and anorexia. In Clemons' s study, the rate of grade 1-2 sedation was increased from 40.8-54.1\%, and more extrapyramidal symptoms were observed in the olanzapine group [9]. Overall, based on published clinical studies, adding olanzapine to standard antiemetic therapy is safe and beneficial.

In addition, NK-1 RA has been recommended for CINV prevention, but numerous cancer patients cannot afford the high cost. Olanzapine antiemetic therapy should be meaningful for patients who do not have access to aprepitant, fosaprepitant, netupitant, fosnetupitant, or rolapitant. In the enrolled prospective studies, the complete response rates in the overall period when patients were treated with olanzapine with or without aprepitant were both $50 \%$. But in the control groups, the complete response rate was $21 \%$ when patients received antiemetic therapy without aprepitant and $38 \%$ when patients were treated aprepitant plus ondansetron and dexamethasone. According to the above results, olanzapine might be an optimal substitute for NK-1 RA in antiemetic treatments. Future studies are needed to confirm this hypothesis.

Several limitations existed in this study. (1) Only two prospective and two retrospective studies were included, which might increase the bias of the assessment. (2) As standard antiemetic regimens in each study were nonuniform, the control rates after adding olanzapine could differ. Nevertheless, although bias existed among the studies, the effects of olanzapine in improving CINV were solid.

\section{Conclusions}

Based on our analysis, olanzapine appeared to effective in the antiemetic therapy of breast cancer. Moreover, due to the low cost, olanzapine is worth being recommended when breast cancer patients are treated with highly emetogenic chemotherapies.

\section{Declarations}

\section{Funding:}

This study was supported by the Hubei Provincial Natural Science Foundation (Grant number: 2020CFB397 to Bi-Cheng Wang) and the Independent Innovation Foundation of Wuhan Union Hospital (Grant number: 2019-109 to Bi-Cheng Wang).

\section{Competing interests:}

No conflict of interest.

\section{Availability of data and materials}

All data extracted from eligible studies can be searched and downloaded from the PubMed database.

\section{Code availability}

N/A.

\section{Authors' contributions}

Study design: Bo-Ya Xiao and Bi-Cheng Wang; data extraction: Bo-Ya Xiao and Bi-Cheng Wang; data analysis: Bi-Cheng Wang and Guo-He Lin; Manuscript writing and edition: all authors.

\section{Ethics approval and consent to participate}

N/A.

\section{Consent to participate}

N/A.

\section{Consent for publication}


All authors have agreed.

\section{Acknowledgements}

We thank all the members in the SNOWELL studio for helping to improve the language.

\section{References}

1. Suehiro M, Kojima Y, Takahashi M, Ito Y, Keira T, Ikegawa K, Minatogawa H, Tsugawa K, Tanaka T. Antiemetic Efficacy of Adding Olanzapine 5 mg to Aprepitant, Palonosetron and Dexamethasone-Sparing After Day Two for Cancer Patients Receiving Anthracycline and Cyclophosphamide. Cancer Manag Res. 2021; 13: 1617-24. doi: 10.2147/cmar.S280995.

2. Kawazoe H, Murakami A, Uozumi R, Yamashita M, Kobayashi-Taguchi K, Kusakabe E, Yamasawa H, Yakushijin Y, Nakamura T, Kamei Y. A four-drug combination of olanzapine, aprepitant, palonosetron, and dexamethasone for nausea and vomiting in patients with breast cancer receiving anthracy cline : A retrospective observational study. Supportive Care in Cancer. 2019; 27: S28. doi: 10.1007/s00520-019-04813-1.

3. Kawazoe H, Uozumi R, Murakami A, Yamashita M, Kobayashi-Taguchi K, Kusakabe E, Yamasawa H, Yakushijin Y, Nakamura T, Kamei Y. Olanzapine plus aprepitant, palonosetron, and dexamethasone for nausea and vomiting in patients with breast cancer receiving anthracycline: A retrospective study. Sci Rep. 2018; 8: 16232. doi: 10.1038/s41598-018-34618-x

4. Zhou JG, Huang L, Jin SH, Xu C, Frey B, Ma H, Gaipl US. Olanzapine combined with 5-hydroxytryptamine type 3 receptor antagonist (5-HT3 RA) plus dexamethasone for prevention and treatment of chemotherapy-induced nausea and vomiting in high and moderate emetogenic chemotherapy: a systematic review and meta-analysis of randomised controlled trials. ESMO Open. 2020; 5. doi: 10.1136/esmoopen-2019-000621.

5. Chow R, Herrstedt J, Aapro M, Chiu L, Lam H, Prsic E, Lock M, DeAngelis C, Navari RM. Olanzapine for the prophylaxis and rescue of chemotherapyinduced nausea and vomiting: a systematic review, meta-analysis, cumulative meta-analysis and fragility assessment of the literature. Support Care Cancer. 2021: 1-21. doi: 10.1007/s00520-020-05935-7.

6. Moher D, Liberati A, Tetzlaff J, Altman DG, Group P. Preferred reporting items for systematic reviews and meta-analyses: the PRISMA statement. J Clin Epidemiol. 2009; 62: 1006-12. doi: 10.1016/j.jclinepi.2009.06.005.

7. Yeo W, Lau TK, Li L, Lai KT, Pang E, Cheung M, Chan VT, Wong A, Soo WM, Yeung VT, et al. A randomized study of olanzapine-containing versus standard antiemetic regimens for the prevention of chemotherapy-induced nausea and vomiting in Chinese breast cancer patients. Breast (Edinburgh, Scotland). 2020; 50: 30-8. doi: 10.1016/j.breast.2020.01.005

8. Tienchaiananda P, Nipondhkit W, Maneenil K, Sa-Nguansai S, Payapwattanawong S, Laohavinij S, Maneechavakajorn J. A randomized, double-blind, placebo-controlled study evaluating the efficacy of combination olanzapine, ondansetron and dexamethasone for prevention of chemotherapy-induced nausea and vomiting in patients receiving doxorubicin plus cyclophosphamide. Ann Palliat Med. 2019; 8: 372-80. doi: 10.21037/apm.2019.08.04.

9. Clemons M, Dranitsaris G, Sienkiewicz M, Sehdev S, Ng T, Robinson A, Mates M, Hsu T, McGee S, Freedman O, et al. A randomized trial of individualized versus standard of care antiemetic therapy for breast cancer patients at high risk for chemotherapy-induced nausea and vomiting. Breast (Edinburgh, Scotland). 2020; 54: 278-85. doi: 10.1016/j.breast.2020.11.002.

10. Flint AJ, Meyers BS, Rothschild AJ, Whyte EM, Alexopoulos GS, Rudorfer MV, Marino P, Banerjee S, Pollari CD, Wu Y, Voineskos AN, Mulsant BH, Group SPIS. Effect of Continuing Olanzapine vs Placebo on Relapse Among Patients With Psychotic Depression in Remission: The STOP-PD II Randomized Clinical Trial. JAMA. 2019; 322: 622-31. doi: 10.1001/jama.2019.10517.

11. Hashimoto H, Abe M, Tokuyama O, Mizutani H, Uchitomi Y, Yamaguchi T, Hoshina Y, Sakata Y, Takahashi TY, Nakashima K, Nakao M, Takei D, Zenda S, et al. Olanzapine $5 \mathrm{mg}$ plus standard antiemetic therapy for the prevention of chemotherapy-induced nausea and vomiting (J-FORCE): a multicentre, randomised, double-blind, placebo-controlled, phase 3 trial. Lancet Oncol. 2020; 21: 242-9. doi: 10.1016/s1470-2045(19)30678-3.

12. Kishi T, Yoshimura R, Sakuma K, Okuya M, Iwata N. Lurasidone, olanzapine, and quetiapine extended-release for bipolar depression: A systematic review and network meta-analysis of phase 3 trials in Japan. Neuropsychopharmacol Rep. 2020; 40: 417-22. doi: 10.1002/npr2.12137.

13. Kugbey N, Oppong Asante K, Meyer-Weitz A. Depression, anxiety and quality of life among women living with breast cancer in Ghana: mediating roles of social support and religiosity. Support Care Cancer. 2020; 28: 2581-8. doi: 10.1007/s00520-019-05027-1.

14. Ju HB, Kang EC, Jeon DW, Kim TH, Moon JJ, Kim SJ, Choi JM, Jung DU. Associations Among Plasma Stress Markers and Symptoms of Anxiety and Depression in Patients with Breast Cancer Following Surgery. Psychiatry Investig. 2018; 15: 133-40. doi: 10.30773/pi.2017.07.26.

15. Pilevarzadeh M, Amirshahi M, Afsargharehbagh R, Rafiemanesh $H$, Hashemi SM, Balouchi A. Global prevalence of depression among breast cancer patients: a systematic review and meta-analysis. Breast Cancer Res Treat. 2019; 176: 519-33. doi: 10.1007/s10549-019-05271-3.

\section{Tables}

Table 1 Characteristic of the selected prospective and retrospective studies. 


\begin{tabular}{|c|c|c|c|c|c|c|c|c|c|c|}
\hline First author & $\begin{array}{l}\text { Publication } \\
\text { year }\end{array}$ & Design & Region & Groups & $\begin{array}{l}\text { No. } \\
\text { patients }\end{array}$ & $\begin{array}{l}\text { Age } \\
\text { (range) }\end{array}$ & $\begin{array}{l}\text { Stage } \\
(\%)\end{array}$ & $\begin{array}{l}\text { Olanzapine } \\
\text { dosage }\end{array}$ & $\begin{array}{l}\text { Standard } \\
\text { antiemetic drugs }\end{array}$ & Chemotheri \\
\hline \multicolumn{11}{|l|}{$\begin{array}{l}\text { Prospective } \\
\text { studies }\end{array}$} \\
\hline Tienchaiananda & 2019 & $\begin{array}{l}\text { A } \\
\text { randomized, } \\
\text { double- } \\
\text { blind, } \\
\text { placebo- } \\
\text { controlled, } \\
\text { single- } \\
\text { centre trial }\end{array}$ & Thailand & $\begin{array}{l}\text { Olanzapine } \\
\text { Placebo }\end{array}$ & $\begin{array}{l}20 \\
19\end{array}$ & $\begin{array}{l}\text { Mean } \\
49.4 \\
(27-67) \\
\\
\text { Mean } \\
47.37 \\
(36-67)\end{array}$ & $\begin{array}{l}\text { I (7.7) } \\
\text { II } \\
(61.5) \\
\text { III } \\
(30.8)\end{array}$ & $\begin{array}{l}10 \mathrm{mg} \text { on } \\
\mathrm{d} 1-4\end{array}$ & $\begin{array}{l}\text { Ondansetron } \\
+ \text { Dexamethasone } \\
\pm \text { Metoclopramide }\end{array}$ & $\begin{array}{l}\text { Doxorubicir } \\
\text { +Cyclophos }\end{array}$ \\
\hline Clemons & 2020 & $\begin{array}{l}\text { A } \\
\text { randomized, } \\
\text { double- } \\
\text { blind, } \\
\text { placebo- } \\
\text { controlled, } \\
\text { multi-centre } \\
\text { trial }\end{array}$ & Canada & $\begin{array}{l}\text { Olanzapine } \\
\text { Placebo }\end{array}$ & $\begin{array}{l}113 \\
105\end{array}$ & $\begin{array}{l}\text { Mean } \\
50(23- \\
74) \\
\text { Mean } \\
52(23- \\
88)\end{array}$ & $\begin{array}{l}\text { I (7.8) } \\
\text { II } \\
(56.0) \\
\text { III } \\
(35.3)\end{array}$ & $\begin{array}{l}5 \mathrm{mg} \text { on } \\
\mathrm{d} 1-4\end{array}$ & $\begin{array}{l}\text { Aprepitant } \\
\text { +Ondansetron } \\
\text { +Dexamethasone }\end{array}$ & $\begin{array}{l}\text { Doxorubicir } \\
\text { +Cyclophos } \\
\text { Fluorouraci } \\
\text { +Epirubicin } \\
\text { +Cyclophos } \\
\text { Docetaxel } \\
\text { +Cyclophos } \\
\text { +Trastuzun }\end{array}$ \\
\hline Yeo & 2020 & $\begin{array}{l}\text { A } \\
\text { randomized, } \\
\text { open-label, } \\
\text { single- } \\
\text { centre trial }\end{array}$ & China & $\begin{array}{l}\text { Olanzapine } \\
\text { Placebo }\end{array}$ & $\begin{array}{l}60 \\
60\end{array}$ & $\begin{array}{l}\text { Median } \\
54.5 \\
(36-71) \\
\\
\text { Median } \\
55.5 \\
(32-71)\end{array}$ & $\begin{array}{l}\text { I (4.2) } \\
\text { II } \\
(62.5) \\
\text { III } \\
(23.3)\end{array}$ & $\begin{array}{l}10 \mathrm{mg} \text { on } \\
\mathrm{d} 1-5\end{array}$ & $\begin{array}{l}\text { Aprepitant } \\
\text { +Ondansetron } \\
\text { +Dexamethasone }\end{array}$ & $\begin{array}{l}\text { Doxorubicir } \\
\text { +Cyclophos }\end{array}$ \\
\hline $\begin{array}{l}\text { Retrospective } \\
\text { studies }\end{array}$ & & & & & & & & & & \\
\hline Kawazoe & 2018 & $\begin{array}{l}\text { A case- } \\
\text { control } \\
\text { study }\end{array}$ & Japan & $\begin{array}{l}\text { Olanzapine } \\
\text { Placebo }\end{array}$ & $\begin{array}{l}22 \\
108\end{array}$ & $\begin{array}{l}\text { Median } \\
51.0 \\
(45-55) \\
\\
\text { Median } \\
55.0 \\
(44-61)\end{array}$ & $\begin{array}{l}\text { I } \\
(11.5) \\
\text { II } \\
(56.9) \\
\text { III } \\
(26.9) \\
\text { IV } \\
(4.6)\end{array}$ & $\begin{array}{l}5 \mathrm{mg} \text { on } \\
\mathrm{d} 1-4\end{array}$ & $\begin{array}{l}\text { Aprepitant } \\
\text { +Palonosetron } \\
\text { +Dexamethasone }\end{array}$ & $\begin{array}{l}\text { Doxorubicir } \\
+ \text { +Cyclophos } \\
\text { Epirubicin } \\
+ \\
\text { Cyclophoss } \\
\text { Epirubicin } \\
+ \\
\text { Cyclophosf } \\
+ \text { +Fluoroura }\end{array}$ \\
\hline Suehiro & 2021 & $\begin{array}{l}\text { A case- } \\
\text { control } \\
\text { study }\end{array}$ & Japan & $\begin{array}{l}\text { Olanzapine } \\
\text { Placebo }\end{array}$ & $\begin{array}{l}82 \\
95\end{array}$ & $\begin{array}{l}\text { Median } \\
49.0 \\
(27-74) \\
\\
\text { Median } \\
50.0 \\
(27-73)\end{array}$ & $\begin{array}{l}\text { I } \\
(16.9) \\
\text { II } \\
(66.1) \\
\text { III } \\
(16.9)\end{array}$ & $\begin{array}{l}5 \mathrm{mg} \text { on } \\
\text { d1-4 }\end{array}$ & $\begin{array}{l}\text { Aprepitant } \\
\text { +Ondansetron } \\
\text { +Dexamethasone }\end{array}$ & $\begin{array}{l}\text { Epirubicin } \\
+ \\
\text { Cyclophosf } \\
\text { Epirubicin } \\
+ \\
\text { Cyclophosf } \\
+ \text { Fluoroura }\end{array}$ \\
\hline
\end{tabular}

Table 2 The rates of complete response and no nausea in breast cancer patients.

\begin{tabular}{|lllllll|}
\hline Groups & \multicolumn{3}{l}{ Complete response rate } & \multicolumn{2}{l|}{ No nausea rate } & \\
\cline { 2 - 7 } & $0-24 \mathrm{~h}$ & $24-120 \mathrm{~h}$ & $0-120 \mathrm{~h}$ & $0-24 \mathrm{~h}$ & $24-120 \mathrm{~h}$ & $0-120 \mathrm{~h}$ \\
\hline Prospective studies & & & & & & \\
\hline Olanzapine & $71.3 \%$ & $82.5 \%$ & $50.0 \%$ & $70.0 \%$ & $66.3 \%$ & $51.3 \%$ \\
\hline Placebo & $48.1 \%$ & $63.3 \%$ & $34.2 \%$ & $43.0 \%$ & $51.9 \%$ & $25.3 \%$ \\
\hline Retrospective studies & & & & & & \\
\hline Olanzapine & $/$ & $/$ & $47.4 \%$ & $/$ & $/$ & $/$ \\
\hline Placebo & $/$ & $/$ & $43.5 \%$ & $/$ & $/$ & $/$ \\
\hline
\end{tabular}

Table 2 The rates of complete response and no nausea in breast cancer patients. 


\begin{tabular}{|lllllll|}
\hline Groups & \multicolumn{3}{l}{ Complete response rate } & \multicolumn{2}{l|}{ No nausea rate } & \\
\cline { 2 - 7 } & $0-24 \mathrm{~h}$ & $24-120 \mathrm{~h}$ & $0-120 \mathrm{~h}$ & $0-24 \mathrm{~h}$ & $24-120 \mathrm{~h}$ & $0-120 \mathrm{~h}$ \\
Prospective studies & & & & & & \\
\hline Olanzapine & $71.3 \%$ & $82.5 \%$ & $50.0 \%$ & $70.0 \%$ & $66.3 \%$ & $51.3 \%$ \\
\hline Placebo & $48.1 \%$ & $63.3 \%$ & $34.2 \%$ & $43.0 \%$ & $51.9 \%$ & $25.3 \%$ \\
Retrospective studies & & & & & & \\
\hline Olanzapine & $/$ & $/$ & $47.4 \%$ & $/$ & $/$ & $/$ \\
\hline Placebo & $/$ & $/$ & $43.5 \%$ & $/$ & $/$ & $/$ \\
\hline
\end{tabular}

\section{Figures}

Search articles (PubMed: 15; Web of Science: 24 ;

EMBASE: 84; Cochrane Library: 27)=150

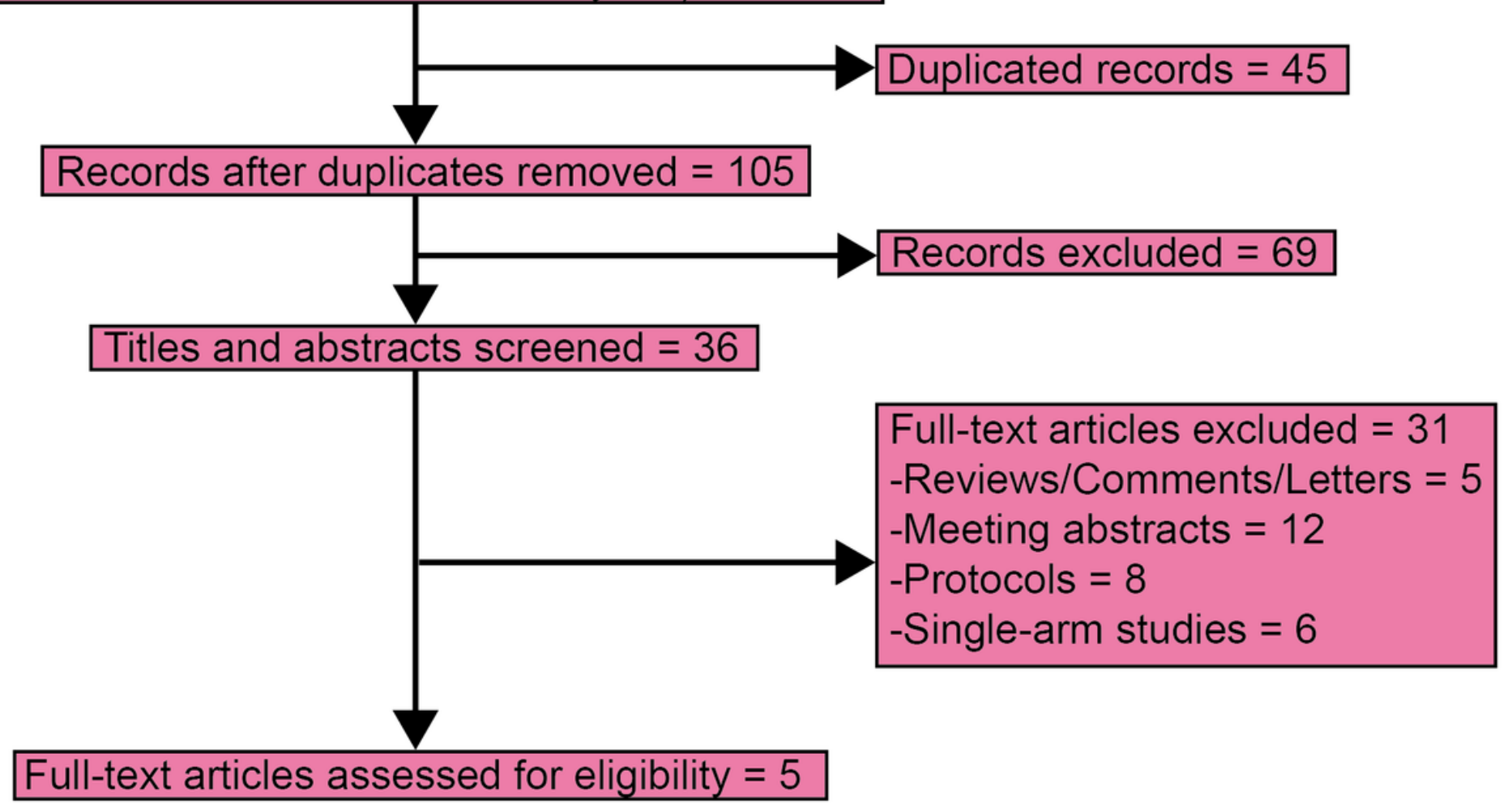

Figure 1

Flow chart of the process of study selection. 
A

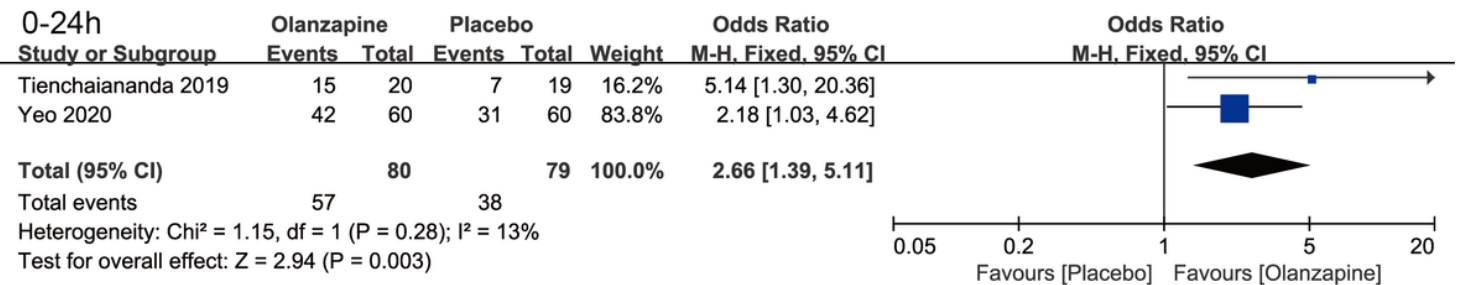

B

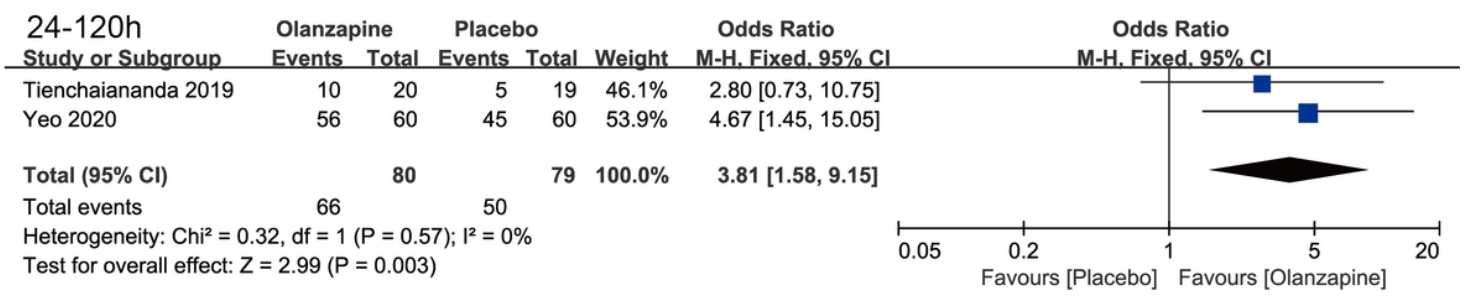

C

0-120h Olanzapine Placebo Odds Ratio Odds Ratio

Study or Subgroup Events Total Events Total Weight M-H. Fixed. $95 \% \mathrm{Cl} \quad \mathrm{M}-\mathrm{H}$, Fixed. $95 \% \mathrm{Cl}$

$\begin{array}{lllllll}\text { Tienchaiananda } 2019 & 10 & 20 & 4 & 19 & 15.1 \% & 3.75[0.92,15.34]\end{array}$

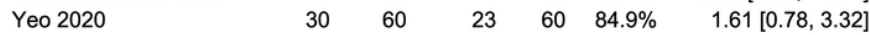

$\begin{array}{lllll}\text { Total }(95 \% \mathrm{Cl}) & 80 & 79 & 100.0 \% & 1.93[1.02,3.66]\end{array}$

Total events $\quad 40 \quad 27$

Heterogeneity: $\mathrm{Chi}^{2}=1.10, \mathrm{df}=1(\mathrm{P}=0.30) ; \mathrm{I}^{2}=9 \%$

Test for overall effect: $Z=2.02(P=0.04)$

$79 \quad 100.0 \% \quad 1.93[1.02,3.66]$

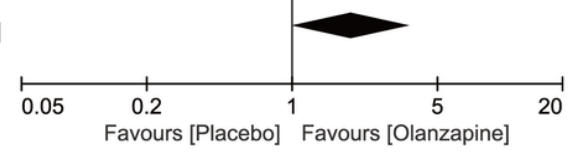

D

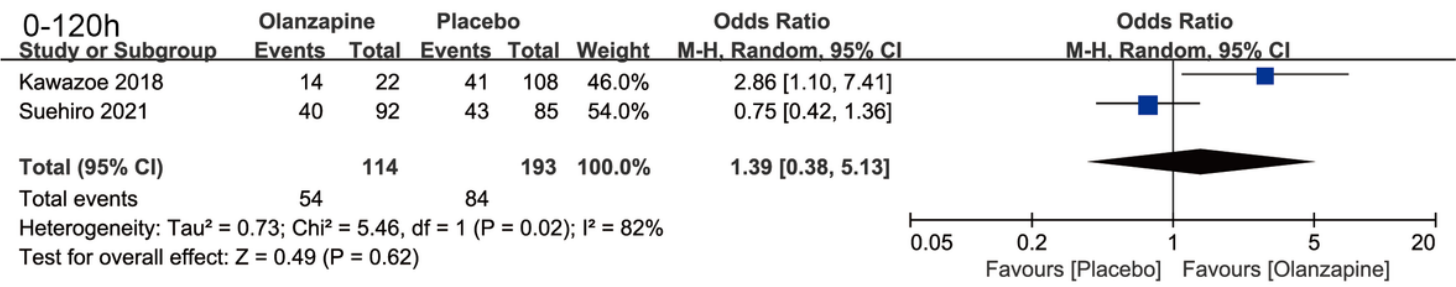

\section{Figure 2}

Forest plots of the complete response rates during the acute $(A)$, delayed $(B)$, and overall period (C and $D[$ retrospective data]). 
A

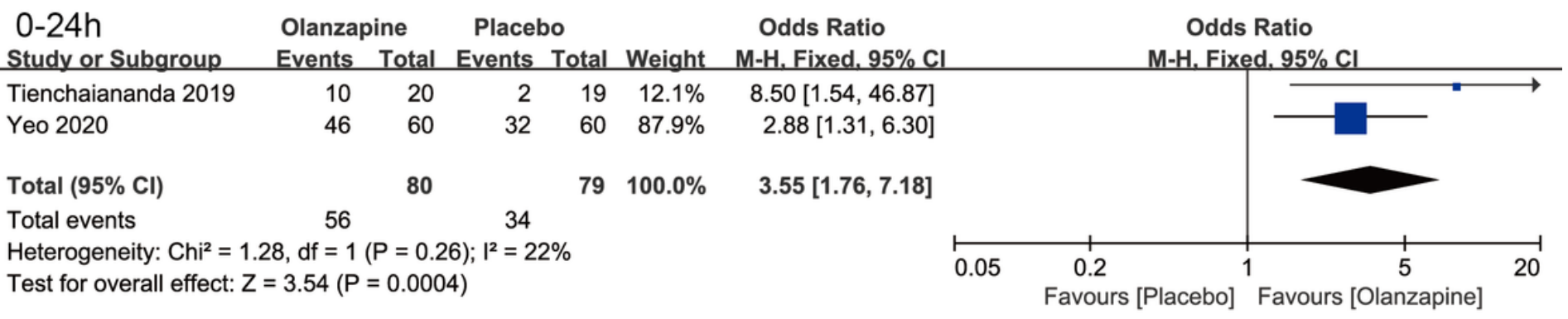

B

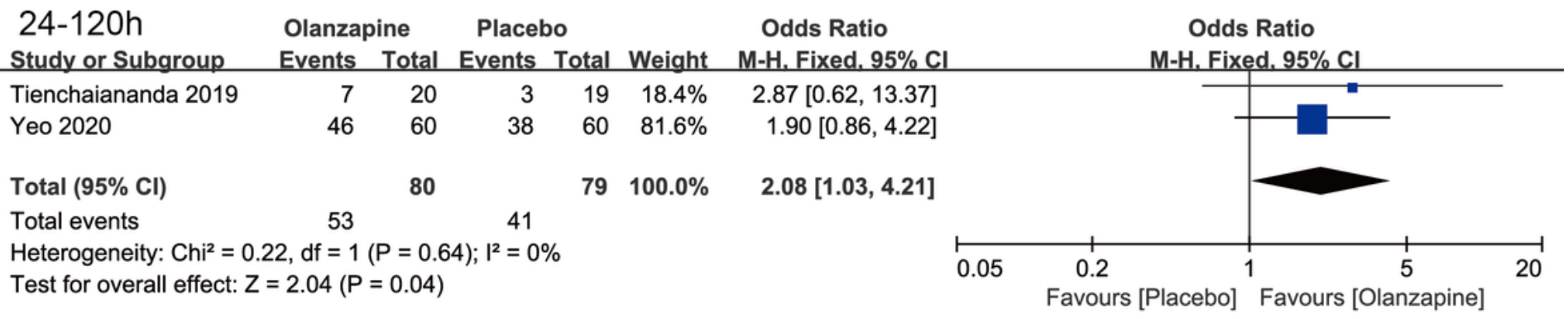

C

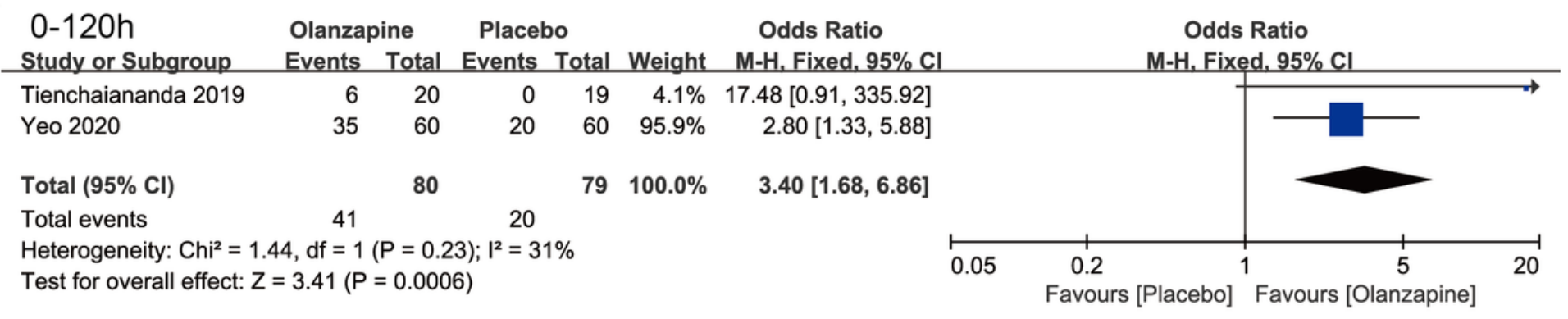

Figure 3

Forest plots of the rates of no nausea in the acute (A), delayed (B), and overall period (C).

\section{Supplementary Files}

This is a list of supplementary files associated with this preprint. Click to download.

- PRISMAchecklist.doc 